\title{
Evaluasi Program PPDB Berbasis Zonasi di SMP Negeri 2 Pabelan
}

\author{
Chatarina Sitoresmi Triwiniastuti \\ Universitas Kristen Satya Wacana \\ chatarina.sitoresmi@gmail.com \\ Bambang Suteng Sulasmono \\ Universitas Kristen Satya Wacana \\ bambang.sulasmono@staff.uksw.edu
}

\begin{abstract}
The admission of new students (PPDB) is a school agenda that is held every year. The purpose of the study is to evaluate the zoning-based PPDB Program in SMP Negeri 2 Pabelan, Semarang Regency. Program evaluation is done by assessing any discrepancies/gaps between the program standards from the central government and the actual conditions of the PPDB program that occurred in SMP Negeri 2 Pabelan. This type of research is a program evaluation research using Discrepancy Model developed by Malcolm Provus. The Discrepancy Model consists of 5 stages: the design stage, the installation stage, the process stage, the product stage, and the cost-benefit analysis stage. However, this research only used 4 stages, namely the design stage, the installation stage, the process stage, and the product stage. Data collection used in this study were, interview, observation, and documentation. The results showed that the design of the category program was sufficient (conformity score $73.3 \%$ ), the installation of the good category program (100\% suitability score), the process of the good category program (suitability score $92.86 \%$ ), and the program product category was good (the suitability score $87.5 \%$ ).
\end{abstract}

Keywords: Zoning, Admission of New Students, PPDB, Discrepancy Model, Program Evaluation

\section{Article Info}

\section{PENDAHULUAN}

Berdasarkan Undang-undang Nomor 20 Tahun 2003 tentang Sistem Pendidikan Nasional, pada intinya menjelaskan bahwa jaminan pendidikan yang diberikan pemerintah kepada setiap warga negaranya adalah pendidikan yang bermutu dan tidak memberikan perlakuan yang berbeda antara warga negara yang satu dengan yang lain. Hal ini berarti sistem penjaminan mutu (quality assurance) sangat diperlukan dalam bidang pendidikan, khususnya pada tahap proses.
Pada tahap proses pendidikan diharapkan berlangsung sesuai dengan standar yang telah ditentukan, sehingga akan menghasilkan sebuah output atau lulusan yang memuaskan bagi pengguna jasa pendidikan. Salis (2010: 30) mengatakan bahwa mutu pendidikan (Quality assurance) menjadi sebuah masalah pokok yang dapat menjamin perkembangan sekolah dalam meraih status di tengah persaingan dunia pendidikan saat ini yang begitu sangat ketat. 
Agar jaminan serta perlindungan pendidikan terhadap semua warga negara bisa terlaksana baik, maka sebaiknya pemerintah bisa memberikan pelayanan yang sama bagi setiap lembaga pendidikan, baik dalam penyediaan sarana prasarana, kualitas tenaga pendidik dan kependidikan, serta penjaminan mutu pendidikan. Dengan demikian terjadi peningkatan dan pemerataan mutu pendidikan pada semua lembaga pendidikan.
Peningkatan dan pemerataan mutu pendidikan merupakan salah satu tuntutan masyarakat Indonesia dalam bidang pendidikan. Namun demikian letak geografis dan kondisi daerah yang berbada-beda menyebabkan sulitnya proses pemerataan mutu pendidikan. Sehingga Kemendikbud terus berupaya untuk mewujudkan pendidikan yang merata dan berkuaitas melalui bermacammacam program dan kebijakan sebagai sasaran prioritas nasional.
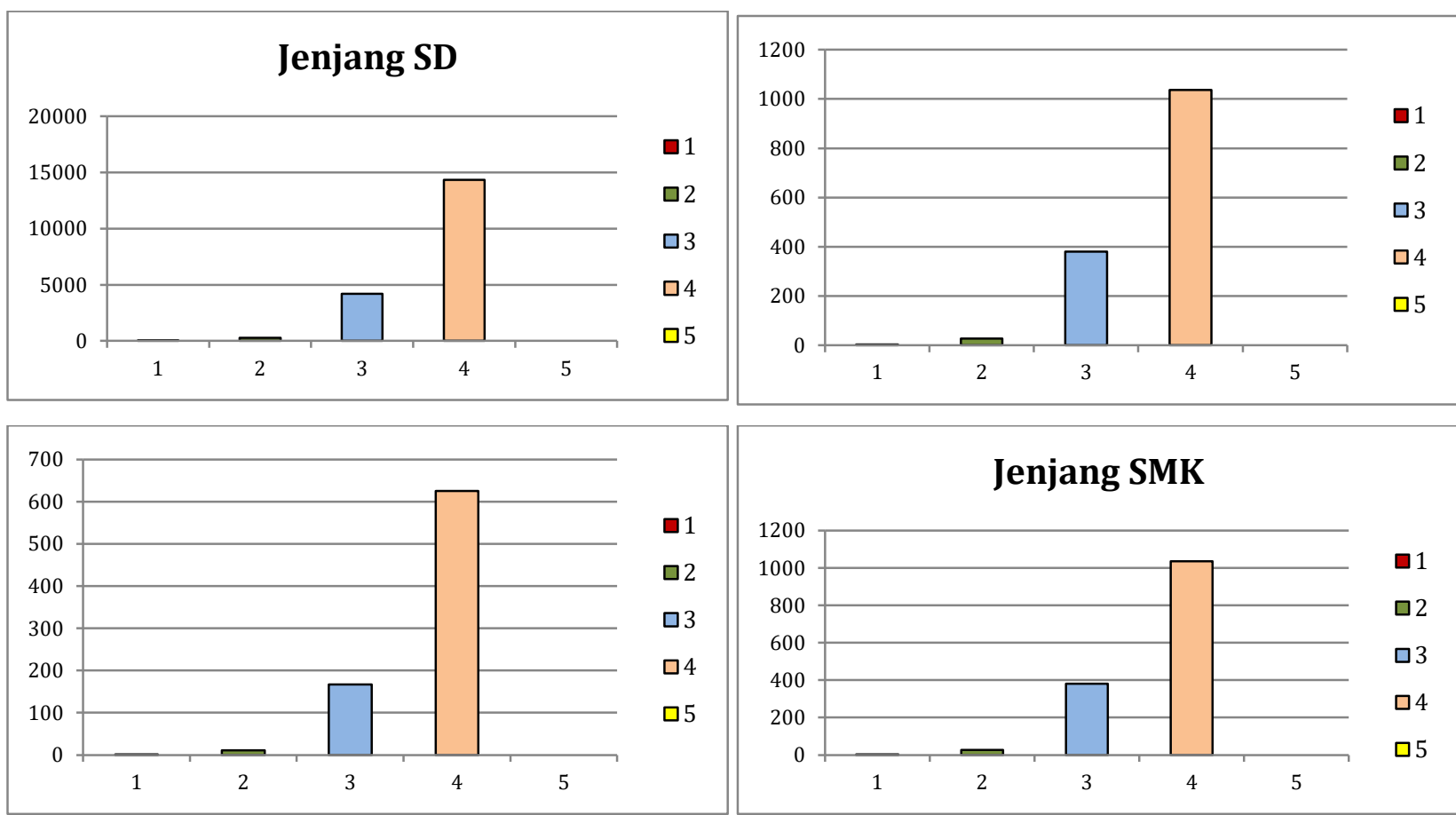

Jenjang SMK

Sumber: LPMP Jawa Tengah Tahun 2017

Gambar 1. Grafik Jumlah Sekolah Berdasarkan Kategori Capaian SNP

Dari gambar di atas menunjukkan bahwa baik pada jenjang SD, SMP, SMA, dan SMK, berada pada level menuju SNP 4, dan belum pada level SNP. Harapannya adalah dengan adanya SNP maka setiap lembaga sekolah memiliki standar kualitas yang sama. Sehingga peserta didik dapat dengan bebas memilih sekolah yang dekat dengan tempat tinggalnya, tanpa ada perbedaan status sekolah favorit dan non-favorit.

Salah satu cara untuk menghilangkan status sekolah favorit dan non-favorit, maka pemerintah membuat sebuah kebijakan yaitu sistem zonasi dalam PPDB. Salah satu tujuan dari sistem zonasi sendiri adalah pemetakan peserta didik pada saat pendaftaran sekolah, disamping bertujuan untuk pemerataan kualitas pendidikan, menghilangkan predikat sekolah favorit, peningkatan kualitas guru, dan mengurangi tingkat kemacetan lalu lintas.

PPDB berbasis zonasi bisa menjadi salah satu alternatif untuk pemerataan peserta didik. PPDB dengan menggunakan sistem zonasi sudah dilaksanakan sejak tahun pelajaran 2017/2018 dengan adanya Permendikbud No. 17 Tahun 2017. Namun 
demikian sejak digulirkannya sistem zonasi PPDB tersebut dalam pelaksanaannya belum benar-benar berbasis zonasi. Perbaikan terus menerus dilakukan oleh pemerintah untuk pelaksanaan program yang lebih baik. Dengan demikian pada saat PPDB, peserta didik yang berada pada wilayah zonasi atau bertempat tinggal dekat dengan sekolah itulah yang diterima.

PPDB merupakan langkah awal dari sebuah manajemen untuk mendapatkan peserta didik, karena PPDB merupakan sebuah program yang mempunyai keterkaitan langsung dengan keberlangsungan lembaga sekolah. Penerimaan siswa baru pada hakekatnya memiliki makna sebagai peristiwa penting bagi suatu sekolah, karena sebagai tonggak penentu keberhasilan sekolah Suharsimi dan Lia (2012: 32). Sedangkan Rugaiyah dan Sismiati (2011:54) menyatakan bahwa penerimaan siswa baru merupakan suatu kegiatan sekolah untuk dapat menampung peserta didik dengan menyesuaikan kuota yang telah ditentukan, fasilitas sekolah, tenaga pendidikan dan kependidikan, serta kemampuan peserta didik dalam mengikuti pembelajaran di sekolah tujuan.

Pernyataan di atas menunjukkan bahwa program PPDB merupakan suatu kegiatan yang sangat penting dimana dilaksanakan pada awal sebelum proses pembelajara guna menyeleksi calon calon peserta didik baru sesuai dengan analisa kebutuhan sekolah seperti, daya tampung, sarana dan prasarana, jumlah guru dan staf.

Salah satu yang menjadi sekolah favorit di wilayah kecamatan Pabelan adalah SMP Negeri 2 Pabelan. Lokasinya berada pada pemukiman penduduk sehingga menjadikan sekolah yang strategis, mudah untuk akses kendaraan, dan sekolah pilihan. Dengan banyaknya peminat yang mendaftar, maka sekolah bebas dalam memilih calon peserta didik, khususnya dalam prioritas pencapaian nilai UN. Nilai peserta didik yang tidak memenuhi kriteria meskipun jarak rumahnya dekat dengan sekolah tetap tidak bisa diterima.

Hal ini menimbulkan sebuah permasalahan, dimana tidak adanya pemerataan peserta didik antara sekolah yang satu dengan yang lain. Disamping itu masyarakat sekitar sekolah merasakan ketidak adilan dalam proses penerimaan peserta didik. Karena mereka tinggal lebih dekat dengan sekolah.

Hasil observasi awal, peneliti menemukan bahwa ada beberapa permasalahan yang terjadi di SMP N 2 Pabelan selama menjalankan PPDB. Permasalahan tersebut adalah, bahwa sekolah selama ini belum pernah benar-benar mengadakan evaluasi secara menyeluruh terhadap input, proses dan output dari program PPDB. Sekolah hanya melihat kualifikasi dan prestasi peserta didik saja. Disamping itu sekolah belum mengadakan evaluasi secara maksimal karena alasan keterbatasan waktu dan belum adanya panduan yang jelas untuk mengevaluasi program tersebut.

Penelitian yang memiliki keterkaitan dengan PPDB berbasis zonasi antara lain penelitian yang dilakukan oleh Bintoro (2018) yang menunjukkan bahwa pelaksanaan PPDB dengan sistem zonasi yang terjadi kota Samarainda menimbulkan pertentangan di masyarakat karena pada saat pelaksanaan PPDB masyarakat belum mendapatkan sosialisasi secara jelas. Dan adanya anggapan bahwa belum semua lembaga sekolah mempunyai standar pendidikan yang sama.

Penelitian yang lain dilakukan oleh Badau dan Yahya (2017) untuk menilai keberhasilan sistem zonasi sekolah klaster di negara bagian Adamawa, Nigeria. Tujuan dari penelitian ini adalah untuk menilai keberhasilan ekonomi, pedagogik, administratif dan politik sistem zonasi klaster di Sekolah Menengah Atas di Negara Bagian Adamawa. Hasil dari penelitian ini menyimpulkan bahwa tujuan ekonomi, pedagogik, administratif dan politik dari sistem zonasi kaster di Sekolah Menengah 
Atas di Negara Bagian Adamawa tidak tercapai.

Adanya gejolak dimasyarakat tidak hanya ditunjukkan oleh penelitian yang dilakukan oleh Bintoro. Tetapi juga ditunjukkan dari hasil penelitian Mahyani, Wahyunengseh dan Haryanti (2019), yaitu adanya kekawatiran bagi siswa berprestasi untuk diterima di sekolah favorit.

Berdasarkan paparan di atas, dari beberapa penelitian menyatakan bahwa sistem zonasi khususnya dalam penerimaan peserta didik, masih ditemukan beberapa permasalahan. Sebagai acuan pelaksanaan PPDB tahun 2019 adalah Permendikbud No. 51 Tahun 2018. Untuk PPDB jalur zonasi minimal 90\%, jalur prestasi maksimal 5\%, dan jalur perpindahan tugas orang tua maksimal 5\%. Sehingga peneliti tertarik untuk mengevaluasi program PPDB berbasis zonasi yang dilakukan di SMP Negeri 2 Pabelan mulai dari desain yang digunakan sampai dengan produk yang dihasilkan dari program tersebut.

\section{METODE PENELITIAN}

Penelitian ini menggunakan evaluasi program dengan Discrepancy Model menurut Malcom Provus dengan empat tahap, yaitu disain, instalasi, proses, dan produk. Sedangkan tahap yang kelima yaitu analisis biaya-manfaat tidak dievaluasi karena lembaga sekolah dalam menjalankan program PPDB semua pembiayaan bersumber dari dana pemerintah (BOS). Lokasi yang penelitian adalah SMP Negeri 2 Pabelan, yang berada di Desa Jembrak, Kecamatan Pabelan, Kabupaten Semarang.

Penelitian dilaksanakan dalam kurun waktu dari bulan November 2019 sampai dengan bulan Februari 2020. Subyek yang diteliti pada penelitian ini adalah Kepala Sekolah, Panitia PPDB, Operator PPDB. Subyek dalam penelitian ini dipandang cocok untuk memberikan informasi-informasi yang dibutuhkan peneliti secara akurat dan obyektif.
Teknik yang digunakan dalam mengumpulkan data, adalah studi dokumentasi, observasi terhadap kegiatan yang diamati, dan wawancara mendalam dengan nara sumber yang terlibat dalam penelitian. Untuk memvalidasi data digunakan teknik triangulasi sumber data dan triangulasi teknik/metode. Dan sebagai analisis data digunakan tahapan reduksi data, kemudian menyajikan data, dan terakhir penarikan kesimpulam.

\section{HASIL PENELITIAN DAN PEMBAHASAN \\ Hasil Penelitian \\ Tahap Disain}

Lima belas (15) disain yang dibuat oleh sekolah dapat dievaluasi tingkat kesesuaiannya dengan disain yang dibuat oleh pemerintah pusat. Dari hasil studi dokumen (Permendikbud No. 51 Tahun 2018) dan berdasarkan wawancara dengan kepala sekolah, panitia PPDB, dan Operator PPDB menunjukkan bahwa ada 4 (empat) aspek yang diterapkan oleh sekolah tidak sesuai dengan disain pemerintah pusat. Sedangkan 11 (sebelas) aspek telah sesuai.

Aspek disain yang telah sesuai adalah, (1) dasar hukum, (2) tujuan PPDB zonasi, (3) prinsip PPDB zonasi, (4) tata cara pelaksanaan PPDB, (5) ketentuan jumlah rombongan belajar, (6) Domisisli calon peserta didik, (7) prosedur pendaftaran, (8) seleksi PPDB, (9) daftar ulang, (10) pelaporan dan pengawasan, serta (11) sanksi. Hal ini artinya antara disain yang dibuat oleh pemerintah pusat dengan realisasi di sekolah tidak terdapat kesenjangan.

Keempat aspek yang tidak sesuai adalah, (1) persyaratan peserta PPDB, (2) ketentuan jumlah peserta didik, (3) jalur pendaftaran, dan (4) biaya PPDB. Pada persyaratan peserta PPDB kesenjangan disebabkan oleh penggunaan ijazah atau STTB sebagai syarat pendaftaran calon peserta didik. Jika pada disain yang dibuat oleh pemerintah pusat menyebutkan bahwa persyaratan peserta 
PPDB harus menggunakan ijazah atau STTB $\mathrm{SD} /$ sederajat, maka pada disain program di sekolah tidak mempersyaratkan penggunaan ijazah atau STTB SD/sederajat bagi pendaftar. Hal ini disebabkan karena pada saat pelaksanaan PPDB belum diadakan UN, sehingga dapat menyulitkan calon pendaftar jika ijasah/STTB dipersyaratkan dalam proses pendaftaran.

Kesenjangan ketentuan jumlah peserta didik adalah penambahan daya tampung maksimal peserta didik untuk setiap rombel/kelas. Jika menurut disain pemerintah pusat untuk jenjang SMP daya tampung setiap rombel/kelas adalah paling sedikit 20 (dua puluh) peserta didik dan paling banyak 32 (tiga puluh dua) peserta didik, maka pada disain program sekolah daya tampung tiap rombel/kelas adalah 34 (tiga puluh empat) peserta didik. Hal ini karena untuk mengantisipasi jika ada peserta didik yang keluar/pindah sekolah.

Kesenjangan jalur pendaftaran yaitu adanya penambahan satu jalur dari tiga jalur yang sudah ditetapkan pemerintah. Jadi pada disain yang dibuat oleh pemerintah pusat terdapat 3 (tiga) jalur saja yaitu, jalur zonasi, jalur prestasi, dan jalur perpindahan tugas orang tua, maka pada disain program di sekolah terdapat 4 (empat) jalur yaitu jalur zonasi, jalur prestasi, jalur perpindahan tugas orang tua, dan jalur pesantren atau asrama di sekitar SMP Negeri 2 Pabelan. Hal ini karena pada wilayah zonasi SMP Negeri 2 Pabelan terdapat pondok pesantren dan asrama atlet yang peserta didiknya bukan berasal dari daerah setempat. Dengan demikian maksud penembahan satu jalur tersebut supaya para santri/atlet tersebut bisa masuk di SMP Negeri 2 Pabelan.

Kesenjangan biaya PPDB yaitu adanya pungutan pembelian seragam sekolah. Jika menurut disain yang dibuat oleh pemerintah pusat menyebutkan bahwa sekolah yang diselenggarakan oleh Pemerintah Daerah dilarang melakukan pungutan untuk membeli seragam atau buku tertentu yang dikaitkan dengan PPDB, maka dalam disain yang dibuat oleh sekolah adalah bagi peserta didik yang dinyatakan diterima dan sudah melakukan daftar ulang diwajibkan membeli seragam sekolah. Hal ini karena pembelian seragam sekolah sudah menjadi tradisi dari tahun ke tahun, dan sudah menjadi kesepakatan bersama antara pihak orang tua peserta didik dengan komite sekolah.

\section{Tahap Instalasi}

Tahap instalasi terhadap keempat aspek yang dievaluasi menunjukkan bahwa antara instalasi yang tersedia di sekolah dengan instalasi kebutuhan yang diatur pada desain sekolah ataupun pemerintah telah terdapat kesesuaian.

Keempat indikator tersebut, adalah: (1) sumber daya manusia, (2) Sarana dan prasarana, (3) pembiayaan, dan (4) jadwal pelaksanaan program. Hal ini artinya dari keempat indikator instalasi tidak terdapat kesenjangan.

Sumber daya manusia yang terlibat dalam program PPDB berbasis zonasi meliputi guru, tata usaha, komite sekolah, masyarakat/orang tua peserta didik, dan dinas pendidikan setempat. Untuk kepanitiaan di sekolah melibatkan guru dan staf tata usaha dengan dasar kualifikasi pengusaan teknologi informasi dan pergiliran tugas. Namun kadang karena keterbatasan orang yang benar-benar menguasai IT, kepanitiaan PPDB sering kali menggunakan orang yang sebagian besar sama dengan tahun sebelumnya. Komite sekolah membantu dalam hal informasi ke luar atau ke masyarakat dan terlibat dalam pemantauan pelaksanaan PPDB. Sedangkan masyarakat /orang tua peserta didik turut mendukung keberhasilan program dengan mematuhi aturan yang berlaku. Meskipun tidak menutup kemungkinan adanya penilaian negatif dari adanya sistem zonasi. Khususnya bagi orang tua yang tidak bisa mendaftar di sekolahan yang dikehendaki. Dan panitia dinas biasanya 
terlibat dalam proses seleksi, pengumuman. Karena semua sudah menggunakan sistem yang terintegrasi.

Sarana dan prasarana untuk mendukung program PPDB diusahakan dan dirancang oleh sekolahan dengan pembiayaan dari BOS. Sarpras dapat menggunakan yang sudah dimiliki sekolah sebelumnya maupun dengan pengadaan/belanja khusus pada saat akan PPDB. Kecuali untuk aplikasi website PPDB telah disediakan oleh pemerintah daerah melalui dinas pendidikan setempat.

Jadwal pelaksanaan PPDB sekolah mengikuti jadwal yang sudah ditetapkan oleh dinas pendidikan setempat. Baik PPDB online, seleksi, pengumuman dan daftar ulang.

\section{Tahap Proses}

Hasil evaluasi pada tahap proses terhadap 3 (tiga) aspek yang diamati yaitu perencanaan, pelaksanaan, dan evaluasi program PPDB. Aspek perencanaan terdiri dari tujuh indikator yaitu pembentukan panitia, sosialisasi, promosi, koordinasi awal, pendataan dan inventaris sarana dan prasarana, pelatihan proktor, dan sosialisasi proktor. Aspek pelaksanaan terdiri dari lima indikator yaitu: pengumuman pendaftaran, pendaftaran, seleksi, pengumuman penerimaan, dan daftar ulang. Dan aspek evaluasi terdiri dari dua indikator yaitu: evaluasi sekolah dan evaluasi tingkat kabupaten/kota.

Setiap indikator pada aspek perencanaan tidak terdapat kesenjangan. Demikian juga indikator pada aspek evaluasi juga tidak terdapat kesenjangan. Namun pada aspek pelaksanaan terdapat kesenjangan hanya pada indikator pendaftaran. Dimana kebijakan yang telah dibuat oleh SMP Negeri 2 Pabelan dengan menambahkan satu jalur PPDB pada akhirnya tidak digunakan. Hal ini karena tidak ada anak pondok/asrama yang mendaftar melalui jalur tersebut. Pondok telah memiliki boarding school sendiri.

\section{Tahap Produk}

Hasil penelitian pada tahap produk terbagi dalam 3 aspek, yaitu hasil program, ketercapaian tujuan dan dampak program. Khusus untuk hasil program terdapat 6 indikator, yaitu ketercapaian kuota jalur zonasi, kuota jalur prestasi, kuota jalur perpindahan tugas orang tua, jalur pondok/asrama, jumlah rombel, dan jumlah peserta didik dalam tiap rombel.

Aspek ketercapaian tujuan dan aspek dampak program tidak terdapat kesenjangan. PPDB berbasis zonasi di SMP Negeri 2 Pabelan telah mencapai tujuan akhir yang sesuai dengan tujuan yang ditetapkan. Hampir sebagian besar (163) peserta didik yang diterima di SMP Negeri 2 Pabelan berasal dari lingkungan sekitar yang menjadi zonasi SMP Negeri 2 Pabelan. Sedangkan 4 (empat) peserta didik menggunakan jalur prestasi yang berasal dari wilayah di luar zonasi. Ketentuan tempat tinggal peserta didik berada pada radius kurang dari 10 (sepuluh) kilo meter berdasarkan titik koordinat yang telah ditetapkan. Pemerataan peserta didik benar-benar telah dirasakan karena pada saat pendaftaran hanya mempersyaratkan jarak terdekat tempat tinggal ke sekolah. Hal ini memberikan dampak bahwa komposisi tingkat keberagaman peserta didik yang diterima sangat tinggi, baik dari latar belakang sosial, ekonomi, dan kompetensi yang dimiliki.

Hasil program PPDB berbasis zonasi kesenjangan terjadi pada aspek jumlah peserta didik dalam tiap rombel. Jika dalam aturannya maksimal adalah 32 peserta didik per rombel, maka faktanya sekolah membuka kesempatan maksimal 34 peserta didik per rombel. Hal ini sebagai antisipasi jika terdapat peserta didk yang keluar/pindah sekolah. Untuk jalur zonasi hanya terisi 4 peserta didik saja yang seharusnya memiliki kuota 8 peserta didik. Sedangkang untuk jalur perpindahan tugas orang tua dan jalur tinggal di pondok sekitar SMP negeri 2 Pabelan pada akhirnya tidak terisi. 


\section{Pembahasan}

\section{Evaluasi Tahap Disain}

Wirawan (2011:7) yang mengatakan bahwa evaluasi merupakan sebuah riset guna mengumpulkan data, menganalisis data, dan menyajikannya dalam bentuk informasi yang bermanfaat tentang obyek evaluasi, serta menilai dengan cara membandingkan antara indikator evaluasi dengan hasil yang dicapai sebagai bahan pertimbangan dalam pengambilan keputusan tentang obyek evaluasi. Sehingga dalam melakukan evaluasi, peneliti juga membandingkan antara disain yang dibuat oleh pemerintah dengan realita yang dilaksanakan di sekolah

Tahap disain, kesenjangan terjadi pada disain persyaratan PPDB, disain ketentuan jumlah peserta didik, disain jalur pendaftaran, dan disain biaya pelaksanaan PPDB. Keempat disain tersebut jelas berbeda dengan disain yang ditetapkan oleh pemerintah pusat. Alasan sekolah membuat 4 (empat) disain yang berbeda dari disain pemerintah adalah karena melihat kondisi senyatanya dilapangan yang tidak memungkinkan untuk mengikuti disain pemerintah maka sekolah membuat disain sendiri. Namun demikian disain yang dibuat memiliki dasar yang kuat untuk bisa dipertanggungjawabkan. Untuk disain persyaratan PPDB merupakan kasus nasional dimana PPDB dilaksanakan sebelum UN. Perbedaan pada disain persyaratan PPDB bukan semata-mata dibuat sendiri oleh sekolah. Melainkan kebijakan dari pemerintah daerah yang menyebabkan adanya kesenjangan. Aturan dari pemerintah pusat telah ditindaklanjuti oleh pemerintah daerah dalam menjawab kebutuhan di lapangan. Supaya aturan pusat bisa dilaksanakan di daerah dengan baik maka pemerintah daerah telah merevisi pada bagian-bagian tertentu yang dianggap perlu sebagai pedoman pelaksanaan di lapangan. Sebagai akibatnya disain yang dilaksanakan di sekolah berbeda dengan disain yang dikeluarkan oleh pusat, karena sekolah mengikuti disain yang dikeluarkan oleh pemerintah daerah.

Sejalan dengan penelitian yang dilakukan oleh Nur, Eka, P., (2018) dalam Design-Reality Gap Penerapan E-Goverment, bahwa dari aspek information: dalam pembuatan disain PPDB kurang adanya koordinasi sehingga disain yang dibuat untuk penggunaan ijasah/SKHU pada kenyataannya tidak dapat dilaksanakan. Hasil penelitian tersebut sama halnya dengan yang terjadi di SMP Negeri 2 Pabelan, bahwa disain yang dibuat oleh pemerintah pusat dalam hal penggunaan ijasah atau STTB tidak dapat terlaksana karena pada saat PPDB belum ada Ujian. Sehingga calon peserta didik belum mempunyai ijasah/STTB.

Disain ketentuan jumlah peserta didik, disain jalur pendaftaran dan disain biaya pelaksanaan PPDB merupakan disain yang dibuat oleh sekolah sebagai bentuk antisipasi dari permasalahan yang bakal muncul di lapangan. Berdasarkan aturan yang ditetapkan pada Permendikbud No. 22 Tahun 2016 tentang Standar Proses Pendidikan Dasar Dan Menengah, dan berdasarkan Permendikbud No. 51 Tahun 2018 tentang aturan PPDB 2019 disebutkan bahwa jumlah peserta didik dalam tiap rombongan belajar untuk jenjang SMP/MTs tidak kurang dari 20 dan tidak lebih dari 32 peserta didik. Akan tetapi, pada kenyataannya SMP Negeri 2 Pabelan membuka peluang pendaftaran untuk tiap rombelnya 34 peserta didik. Kebijakan ini diambil sebagai bentuk antisipasi jika pada perjalanan peserta didik selama 3 (tiga) tahun tidak bisa menyelesaikan masa studinya karena keluar/pindah sekolah. Meskipun dalam praktiknya daya tampung yang dibuka sebanyak 5 (lima) rombel dengan 34 peserta didik per rombel hanya terpenuhi pada saat tahap seleksi saja. Setelah proses daftar ulang hanya 167 peserta didik yang melakukan daftar ulang. 
Meskipun kebijakan yang diambil sekolah dalam hal jumlah maksimal peserta didik dalam tiap rombel tidak sesuai dengan aturan yang berlaku, tetapi sekolah masih tetap memilih cara tersebut. Dalam hal ini sistem Dapodikdasmen masih bisa menerima kelebihan jumlah peserta didik per rombel dengan menggunakan perhitungan rasio jumlah peserta didik. Jika jumlah peserta didik yang diterima di SMP Negeri 2 Pabelan sebanyak 170 peserta didik, maka rasio rombel adalah $170: 32=5,31$ (pembulatan 6). Dalam hal ini sekolah boleh membuka rombel maksimal 6 (enam) rombel. Akan tetapi karena sekolah hanya membuka 5 (lima) rombel, maka ada peluang untuk menambah jumlah peserta didiknya dalam tiap rombel. Hanya saja akan berpengaruh sedikit pada saat akreditasi atau penilaian evaluasi diri sekolah (EDS), (Dapodikdasmen Kementrian Pendidikan dan Kebudayaan).

Disain jalur pendaftaran, terdapat kesenjangan. Sesuai dengan Permendikbud Nomor 51 Tahun 2018 tentang aturan PPDB 2019 terdapat 3 (tiga) jalur pendafataran. Yaitu jalur zonasi, jalur prestasi dan jalur perpindahan tugas orang tua. Namun pada disain yang dilaksanakan di SMP Negeri 2 Pabelan ditambah 1 (satu) jalur lagi yaitu, jalur tinggal di pesantren, asrama di sekitar wilayah SMP Negeri 2 Pabelan.

Penambahan jalur PPDB boleh dilakukan selama tetap menggunaan Peraturan Menteri yang berlaku sebagai acuannya. Hal ini senada dengan pendapat yang disampaikan oleh Wakil Ketua Komisi X DPR Abdul Fikri Fakih, yang mengatakan bahwa pemerintah daerah akan diberikan otoritas yang cukup untuk membuat petunjuk teknis tentang PPDB. Dalam pembuatan juknis harus disesuaikan dengan kondisi daerah atau wilayah setempat. Sehingga daerah mempunyai ruang gerak yang lebih leluasa untuk membuat kebijakan yang sesuai. (Republika.co.id, Rabu 16 Januari 2019).
Disamping itu penambahan jalur PPDB bukan berarti menambahkan kuota tersendiri. Penambahan ini masuk ke dalam jalur zonasi sehingga sering disebut dengan jalur zonasi kombinasi. Dimana total daya tampungnya tetap mengacu pada Peraturan Menteri yaitu minimal $90 \%$.

Nurlailiyah (2019) dalam penelitiannya menyebutkan bahwa, peraturan tentang PPDB dari pemerintah pusat diturunkan kepada pemerintah daerah untuk dirancang sesuai tujuan PPDB di daerah serta melibatkan peran serta pemda dan musyawarah kelompok kerja kepala sekolah (MKKS) dengan tetap mengacu pada Peraturan Menteri tentang PPDB.

Dengan melihat kondisi wilayah maka sekolah mengambil kebijakan tersebut untuk memberikan kesempatan kepada siapapun yang berusia tidak lebih dari 15 tahun untuk bersekolah. Juga sebagai bentuk upaya dalam mendukung wajib belajar 9 (sembilan) tahun. Sesuai dengan Undang-undang Pendidikan Nasional No. 2/1989. Pemerintah berusaha meningkatkan taraf hidup rakyat dengan mewajibkan semua warga negara Indonesia yang berusia 7-12 tahun dan 12-15 tahun untuk menamatkan pendidikan dasar dengan program 6 tahun di SD dan 3 tahun di SLTP secara merata. Keduanya tidak terintegrasi secara fisik melainkan tetap menjadi dua lembaga yang terpisah, dengan kelompok belajar kelas I sampai dengan Kelas VI untuk jenjang SD dan Kelas I sampai Kelas III untuk SLTP (Nawawi, 1994: 351).

Sama halnya dengan disain biaya pelaksanaan PPDB juga mengalami kesenjangan. Masalah pembiayaan adalah masalah yang paling rawan. Terlebih lagi jika tujuan dan penggunaan dana tersebut tidak transparan. Dalam Permendikbud No 51 Tahun 2018 tentang aturan PPDB tahun 2019 menyebutkan bahwa "Pelaksanaan PPDB pada sekolah yang menerima dana BOS tidak dipungut biaya (gratis)". Pasal 33 ayat $3 \mathrm{~b}$ menyebutkan pula bahwa, "Sekolah yang 
diselenggarakan oleh Pemerintah Daerah dilarang melakukan pungutan untuk pembelian seragam atau buku tertentu yang dikaitkan dengan PPDB".

Ketika peserta didik dinyatakan diterima kemudian melakukan daftar ulang, pada saat itu juga peserta didik diwajibkan untuk membeli seragam sekolah yang menjadi ketentuan di SMP Negeri 2 Pabelan. Sekolah mengambil kebijakan yang berbeda dari aturan Menteri tersebut khususnya pada pasal 33 ayat 3b. Hal ini karena sekolah mempunyai dasar yang kuat untuk dapat mempertanggungjawabkan keputusan yang diambil.

Berdasarkan hasil kajian literasi dari Permendikbud Nomor 75 Tahun 2016 tentang Komite Sekolah. Pasal 10 Ayat (1) menjelaskan bahwa "Komite Sekolah melakukan penggalangan dana dan sumber daya pendidikan lainnya untuk melaksanakan fungsinya dalam memberikan dukungan tenaga, sarana dan prasarana, serta pengawasan pendidikan. Selanjutnya pasal 10 ayat (2) menyebutkan bahwa "Penggalangan dana dan sumber daya pendidikan lainnya sebagaimana dimaksud pada ayat (1) berbentuk bantuan dan/atau sumbangan, bukan pungutan. "Sumbangan Pendidikan adalah pemberian berupa uang/barang/jasa/ oleh peserta didik, orang tua/walinya, baik perseorangan maupun bersama-sama, masyarakat atau lembaga sevara sukarela, dan tidak mengikat satuan pendidikan". Artinya pembelian seragam itu sudah menjadi kesepakatan bersama antara orang tua peserta didik dengan komite sekolah yang berbentuk sumbangan.

Demikian juga Peraturan Menteri Pendidikan dan Kebudayaan Nomor 45 Tahun 2014 tentang Pakaian Seragam Sekolah Bagi Peserta Didik Jenjang Pendidikan Dasar dan Menengah, mendukung jika perlu adanya keseragaman dalam berpakian di sekolah. Karena dengan berseragam dapat menanamkan dan menumbuhkan rasa nasionalisme, kebersamaan, serta memperkuat persaudaraan, semangat kesatuan dan persatuan di kalangan peserta didik; meningkatkan rasa kesetaraan tanpa memandang kesenjangan sosial ekonomi orangtua/wali peserta didik; meningkatkan disiplin dan tanggungjawab peserta didik serta kepatuhan terhadap peraturan yang berlaku; serta sebagai acuan bagi sekolah dalam menyusun tata tertib dan disiplin peserta didik khususnya yang mengatur pakaian seragam sekolah. Dengan pertimbangan tersebut, maka sekolah sangat mendukung untuk diberlakukannya seragam sekolah.

Hal ini sejalan pula dengan Peraturan Pemerintah No. 19 Tahun 2005 tentang standar nasional pendidikan. Dalam bab IX pasal 62 disebutkan bahwa, "Standar pembiayaan sekolah meliputi pembiayaan pendidikan yang berupa biaya investasi, biaya operasional, dan biaya personal". Yang dimaksud biaya personal adalah biaya pendidian yang harus dikeluarkan oleh peserta didik/orang tua agar bisa mengikuti proses pembelajaran secara teratur dan berkelanjutan. Dengan demikian apabila sekolah mewajibkan membeli seragam yang menjadi ketentuan sekoloh, bukan berarti sekolah melakukan pelanggaran karena memungut biaya dari peserta didik. Meskipun ada kebijakan sekolah gratis, bukan berarti semua tanpa biaya. Sekolah bisa bekerja sama dengan komite sekolah dalam hal pembiayaan sekolah yang belum bisa terpenuhi dari dana BOS.

Menurut penelitian yang dilakukan oleh Bauman dan Krskova (2016), menyebutkan juga bahwa seragam berkontribusi pada kedisiplinan yang lebih baik dalam kegiatan sekolah sehari-hari. Sehingga dengan menggunakan seragam sekolah dapat meningkatkan kedisiplinan dan memungkinkan untuk pembelajaran yang lebih baik.

Dengan demikian dapat disimpulkan bahwa kebijakan untuk menggunakan seragam sekolah memberikan dampak yang lebih baik terhadap peserta didik. Sehingga apabila 
sekolah mewajibkan penggunaan seragam dengan membeli seragam melalui komite sekolah, bukan berarti sekolah melakukan pelanggaran.

\section{Evaluasi Tahap Instalasi}

Meskipun pada tahap instalasi tidak terdapat kesenjangan pada keempat aspek yang diteliti, bukan berarti pada aspek sumber daya manusia, sarana dan prasarana, pembiayaan tidak terdapat masalah. Namun demikian permasalahan pada ketiga aspek tersebut dapat teratasi dengan baik pada saat pelaksanaan. Sedangkan pada aspek penjadwalan pelaksanaan PPDB tidak terdapat masalah sama sekali, karena sekolah telah mengikuti dan melaksanakan sesuai jadwal yang sudah dibuat oleh pemerintah daerah melalui dinas pendidikan.

Aspek sumber daya manusia permasalahan yang terjadi karena kurangnya sosialisasi dan informasi tentang PPDB zonasi dan keterbatasan SDM yang benar-benar menguasai IT. Sedangkan pada aspek sarana dan prasarana munculnya permasalahan karena keterbatasan beberapa alat dan barang yang akan digunakan untuk mendukung pelaksanaan PPDB berbasis zonasi tersebut. Kendala pada jaringan internet sekolah karena lokasi sekolah yang berada di pedesaan sehingga sinyal internet kurang bagus. Meskipun dengan sarpras yang terbatas bukan berarti tidak dapat melaksanakan program tersebut. Program tetap berjalan meskipun terdapat keterbatasana pada beberapa sarana dan prasarana yang digunakan.

Namun demikian dalam pelaksanaan program PPDB berbasis zonasi permasalahan yang muncul pada kedua aspek tersebut tidak memberikan dampak yang besar dan dapat teratasi dengan baik.

Sedangkan dalam aspek pendanaan program PPDB permasalahan muncul karena adanya perbedaan alokasi pendanaan dari BOS. Dimana untuk BOS PPDB hanya bisa digunakan untuk pengadaan alat tulis kantor, penggandaan formulir, penyediaan konsumsi, transportasi untuk koordinasi dengan dinas pendidikan kota/kabupaten, publikasi/ pengumuman, biaya layanan daring PPDB dan juga biaya untuk kegiatan pengenalan lingkungan sekolah (MPLS). Artinya kebutuhan di luar tersebut di atas meskipun untuk mendukung pelaksanaan PPDB tetap tidak bisa diambilkan dari dana BOS PPDB. Seperti pembelian komputer, pembelian printer, maka pendanaan berasal dari BOS dengan alokasi pembeliaan dan perawatan alat multi media pembelajaran. Aturan seperti ini diberlakukan agar tidak ada penyalahgunaan anggaran karena anggaran ganda.

Aprilia \& Rosdiana (2017) mengatakan bahwa implementasi kebijakan PPDB di SMA Negeri 4 Kota Madiun untuk sumber daya manusia, penyediaan sarana dan fasilitas, finansial, dan waktu tidak terdapat hambatan. Demikian juga penelitian yang dilakukan oleh Sularto, Wahyudi dan Sukmawati (2018) memberikan gambaran tentang perencanaan calon siswa berbasis online, mengatur penerimaan siswa secara online, pelaksanaan calon siswa secara online, pengawasan penerimaan siswa secara online, dan evaluasi secara online terhadap calon siswa di SMA N 2 Singkawang. Sehingga untuk mendukung program tersebut perlu adanya kesiapan SDM, pengawasan, dan fasilats jaringan internet dan listrik yang memadai dan kedua fasilitas ini harus dipastikan dalam kondisi baik.

Melihat kedua penelitian terdahulu di atas mempunyai kesamaam dengan yang peneliti lakukan saat ini bahwa, perlu adanya kesiapan sumber daya manusia, sarana dan prasarana, finansial/pembiayaan dan waktu pelaksanaan. Hanya saja pada penelitian yang dilakukan oleh Aprilia menggunakan teori Van Metter dan Van Horn, sedangkan yang peneliti lakukan saat ini menggunakan teori model kesenjangan (Discrepancy Model). Sedangkan penelitian yang dilakukan oleh Sularto, Wahyudi \& Sukmawati hanya menekankan pada aspek SDM, pengawasan, dan fasilats 
jaringan internet dan listrik. Namun demikian pada hakikatnya beberapa penelitian ini mempunyai tujuan yang sama yaitu mengevaluasi kesiapan pada tahap instalasi.

\section{Evaluasi Tahap Proses}

Tahap ketiga atau tahap proses, dimana untuk melaksanakan program PPDB berbasis zonasi membutuhkan proses yang panjang mulai dari persiapan awal sampai dengan hasil akhir program. Hal ini sejalan dengan pendapat Sukardi (2014: 4) yang mengatakan bahwa salah satu hasil dari sebuah kebijakan adalah program, dimana untuk menetapkannya melewati proses yang panjang, serta dalam pelaksanaannya telah disepakati bersama oleh para pengelolanya.

Pada tahap proses program PPDB berbasis zonasi, terdapat 3 (tiga) aspek yang dievaluasi yaitu aspek perencanaan, aspek pelaksanaan dan aspek evaluasi. Pada aspek perencanaan semua jenis kegiatan persiapan PPDB telah berjalan dengan baik sesuai dengan juknis yang ada. Terdapat sedikit permasalahan dalam tahap perencanaan ini, yaitu kurangnya persiapan dari sekolah dalam hal promosi dan sosialisai.

Bintoro (2018), kurangnya sosialisasi ke masyarakat tentang PPDB dengan sistem zonasi menyebabkan gejolak di masyarakat dalam pelaksanaan program PPDB zonasi. Hal ini sama halnya dengan permasalahan yang dihadapi SMP Negeri 2 Pabelan, meskipun masyarakat pada akhirnya tetap bersedia untuk mengikuti aturan yang berlaku.

Sedangkan pada tahap pelaksanaan, sudah sebagian besar pelaksanaannya sesuai dengan disain dan instalasi program sekolah. Akan tetapi, pada indikator pendaftaran saja yang muncul kesenjangan. Sehingga kebijakan penambahan jalur yang sudah dibuat oleh sekolah sebagai respon dari kondisi masyarakat sekitar sekolah pada akhirnya tidak digunakan. Hal ini karena pada saat PPDB tahun 2019 tidak terdapat siswa dari pondok yang masuk/mendaftar ke SMP Negeri 2 Pabelan sebagai akibat telah dibukanya boarding school di pondok tersebut.

Ardhi M.I. (2015) mengatakan juga bahwa manajemen program PPDB di Dinas Pendidikan Kota Yogyakarta meliputi: perencanaan PPDB, implementasi PPDB, pengorganisasian PPDB (kepanitiaan), dan pengendalian dan evaluasi. Dari penelitian di atas secara garis besar memiliki kesamaan dengan prosedur PPDB yang dilaksanakan di SMP Negeri 2 Pabelan. Hanya saja dalam penelitian tersebut tidak ada pembagian lagi dari tiap-tiap tahapan yang ada.

Pramachintya \& Sutrisno

(2015) mengatakan pula bahwa dalam rangka kegiatan penerimaan peserta didik baru dimulai dari persiapan yang matang yang meliputi promosi, pembentukan panitia, perencanaan waktu, persiapan administrasi, persiapan sarpras. Kemudian proses pelaksanaan penerimaan peserta didik baru yang meliputi pengambilan formulir, pengisian formulir, pelaksanaan tes, seleksi, pengumuman, dan daftar ulang. Relevansi penelitian di atas dengan penelitian di SMP Negeri 2 Pabelan adalah adanya tahapan persiapan dan pelaksanaan program PPDB, tetapi pada penelitian tersebut tidak dilakukan tahap evaluasi setelah pelaksanaan seperi di SMP Negeri 2 Pabelan.

\section{Evaluasi Tahap Produk}

Tahap keempat dalam discrepancy model adalah tahap produk. Pada tahap produk program PPDB berbasis zonasi terdapat tiga aspek yang dievaluasi, yaitu aspek hasil program, ketercapaian tujuan, dan dampak program. Pada ketiga aspek tersebut pada dasarnya sudah sebagian besar terlaksana sesuai dengan stadar yang diharapkan. Hanya saja pada aspek hasil program terdapat sedikit kesenjangan khususnya pada jumlah peserta didik per rombel. Dimana sekolah mengambil kebijakan jumlah maskimalnya adalah 34 peserta didik dalam tiap rombel. Meskipun setelah proses daftar ulang harapan 34 peserta didik per rombel tidak seleuruhnya terpenuhi. 
Karena saat proses seleksi sudah menerima 170 peserta didik, tetapi pada saat daftar ulang hanya 167 peserta didik. Sehingga ada rombel yang berisi 33 peserta didik, dan ada rombel yang berisi 34 peserta didik.

Hal ini menyebabkan kesenjangan antara standar yang ditetapkan pemerintah dengan fakta di sekolah. Kebijakan ini diambil dengan alasan untuk mengantisipasi jika ada peserta didik yang keluar/pindah sekolah. sehingga tidak mengurangi dari jumlah yang ditentutan. Disamping itu sekolah berani mengambil kebijakan ini karena saat singkronisasi dengan Dapodikdasmen masih tidak bermasalah dengan hitungan rasio jumlah rombel kelas VII.

Tujuan program juga telah tercapai dengan baik, yaitu memberikan akses dan keadilan terhadap pendidikan bagi semua kalangan masyarakat dengan memberikan prioritas lebih kepada calon peserta didik untuk masuk sekolah yang dekat dengan zonasi tempat tinggalnya.

Hal ini sejalan dengan penelitian terdahulu yang dilakukan oleh Ihlanfeldt (2019) yang menyebutkan bahwa salah satu masalah utama dalam sistem pendidikan di US, adalah bahwa siswa berkulit hitam dan Hispanik akan terpusat pada sekolah-sekolah yang berkualitas rendah dimana sebagian besar siswa berasal dari keluarga miskin. Namun demikian terdapat bukti bahwa kaum minoritas akan berprestasi lebih baik dalam ujian standar jika mereka bersekolah di sekolah yang tidak miskin. Sebagai salah satu strategi untuk mengurangi kaum minoritas di sekolah miskin dan berkualitas rendah adalah dengan membuka perumahan yang terjangkau di zona sekolah yang lebih baik (SAZs). Dari penelitian diatas jelas bahwa ada keadilan dalam bidang pendidikan untuk semua masyarakat baik dari latar belakang sosial, ekonomi, dan pendidikan.

Demikian juga dengan penelitian yang dilakukan oleh Pratama \& Bagadjati (2019), yang menyatakan bahwa penetapan kebijakan 44 zonasi di Sekolah Menengah Atas Negeri telah berhasil dilaksanakan. Demikian juga dengan yang peneliti lakukan di SMP Negeri 2 Pabelan telah terlaksana dengan baik meskipun terapat sedikit permasalahn di lapangan, namun tetap bisa teratasi dengan baik.

Dampak program juga tidak terdapat kesenjangan karena dampak yang dirasakan sekolah telah sesuai dengan disain tentang dampak program. Dimana jarak antara rumah dengan sekolah menjadi dekat. Selain itu sekolah akan menerima peserta didik dengan komposisi yang sangat heterogen dari aspek sosial, ekonomi, dan kompetensi yang dimiliki.

Oleh karena itu tujuan dari penelitian ini adalah untuk melihat adanya kesenjangan dalam pelaksanaan program PPDB berbasis zonasi mulai dari pembuatan disain sampai dengan produk program yang dihasilkan. Widoyoko (2010: 50) mengatakan bahwa evaluasi kesenjangan bertujuan untuk mengetahui tingkat kesesuaian antara standard yang sudah ditentukan dalam program dengan penampilan aktual dari program tersebut.

\section{SIMPULAN DAN SARAN \\ Simpulan}

Hasil penelitian program PPDB berbasis zonasi di SMP Negeri 2 Pabelan dengan model kesenjangan atau discrepancy model, dapat disimpulkan bahwa:

1. Desain Program PPDB Berbasis Zonasi di SMP Negeri 2 Pabelan, termasuk kategori cukup (mendapat skor kesesuaian 73,3\%) karena dari 15 aspek yang dievaluasi terdapat 4 aspek yang memiliki kesenjangan dengan desain PPDB yang ditetepkan pemerintah.

2. Instalasi Program PPDB Berbasis Zonasi di SMP Negeri 2 Pabelan, termasuk kategori baik (mendapat skor kesesuaian 100\%) karena dari 4 aspek yang dievaluasi tidak terdapat kesenjangan dengan desain instalasi yang ditetapkan oleh sekolah ataupun pemerintah. 
3. Proses Program PPDB Berbasis Zonasi di SMP Negeri 2 Pabelan, termasuk kategori baik (mendapat skor kesesuaian 92,86\%) karena dari 14 indikator yang dievaluasi hanya terdapat 1 indikator yang memiliki kesenjangan dengan rencana dalam desain dan instalasi program sekolah.

4. Produk Program PPDB Berbasis Zonasi di SMP Negeri 2 Pabelan, termasuk kategori baik (mendapat skor kesesuaian 87,5\%) karena dari 8 indikator yang dievaluasi hanya terdapat 1 indikator yang memiki kesenjangan dengan desain produk yang ditetapkan sekolah.

\section{Saran}

Berdasarkan hasil simpulan dari program PPDB yang telah diuraikan, maka saran yang dapat peneliti berikan adalah:

Bagi kepala sekolah SMP Negeri 2 Pabelan dalam melaksanakan program PPDB berbasis zonasi perlu adanya manajemen pengorganisasian yang lebih baik, mulai dari perencanaan sampai evaluasi sehingga proses pelaksanaan PPDB berbasis zonasi bisa berjalan lebih baik lagi. Selain itu jika dengan sangat terpaksa sekolah harus membuat kebijakan lokal yang dapat mengakibatkan kesenjangan, sebaiknya tetap memperhatikan tujuan PPDB berbasis zonasi. Kebijakan lokal yang berdampak negatif dapat membuka celah yang bisa disalahgunakan, seperti penerimaan peserta didik titipan, pungutan sekolah, dan lain-lain. Apalagi sampai membuat kebijakan lokal yang pada akhirnya tidak berfungsi karena tidak ada peserta didik yang mendaftar menggunakan jalur tersebut.

\section{DAFTAR PUSTAKA}

Ardhi, M.I., (2015), Evaluasi Manajemen Penerimaan Peserta Didik Baru Sistem Real Time Online Dinas Pendidikan Kota Yogyakarta, Jurnal Penelitian Ilmu Pendidikan, 8 (1), 80-94.
Arikunto, Suharsimi, Yuliana, L., 2012, Manajemen Pendidikan. Yogyakarta Aditya Media Yogyakarta

Badau dan Yahya, (2017), Assessing the Success of School Cluster Zoning System in Senior Secondary Schools of Adamawa State, Nigeria, Journal of Middle East and North Africa Sciences 2017; 3(4).

Baumann, C. dan Krskova, H., (2016), School Discipline, School Uniforms and Academic Performance, International Journal of Educational Management, 30 (6), 1003-1029

Ihlanfeldt, Keith, (2019), The deconcentration of minority students attending bad schools: The role of housing affordability within school attendance zones containing good schools, Journal of Housing Economics, 43, 83-10.

Nawawi, H., dan Martini, M., 1994, Kebijakan Pendidikan di Indonesia Ditinjau Dari Sudut Hukum, Yogyakarta : UGM Press.

Lestari H.A., dan Rosdiana, W., (2017), Implementasi Kebijakan Penerimaan Peserta Didik Baru (PPDB) Di SMA Negeri 4 Kota Madiun Tahun 2017, Jurnal Publika, 6 (5), 1-7.

Mahyani, Wahyunengseh dan Haryanti, (2019), Public Perception of Zoning School Policy in Surakarta Public Senior High Schools, Atlantis Press, 343, 274-278.

Marhaeni, AAIN, 2007, Evaluasi Program Pendidikan, Singaraja, Undiksha.

Nur, Eka Purnama, (2018), Design-Reality Gap Penerapan E-Goverment (Studi Kasus Program PPDB Online di Dinas Pendidikan Kota Mojokerto, Repository, Universitas Airlangga, Surabaya 
Nurlailiyah, Aris, 2019, Analisis Kebijakan Sistem Zonasi Terhadap Perilaku Siswa SMP di Yogyakarta, Jurnal Realita, 17 (1), 13-21.

Peraturan Pemerintah No. 19 Tahun 2005 tentang Standar Nasional Pendidikan.

Permendikbud No. 45 Tahun 2014 tentang Pakaian Seragam Sekolah Bagi Peserta Didik Jenjang Pendidikan Dasar dan Menengah

Permendikbud No. 22 Tahun 2016 tentang Standar Proses Pendidikan Dasar Dan Menengah

Permendikbud No. 75 Tahun 2016 tentang Komite Sekolah

Permendikbud No. 17 Tahun 2017 Tentang $P P D B$

Permendikbud No. 51 Tahun 2018 tentang Aturan PPDB 2019

Pramachintya, D.R., dan Sutrisno, Budi, (2015), Strategi Penerimaan Peserta Didik Baru di SD Muhammadiyah Program Khusus Boyolali, Jurnal Varidika, Kajian Penelitian Pendidikan, 27 (1), 55-61.

Ratih Fenty A. Bintoro, 2018, Public Perception Regarding Policy Implementation On School Zoning Policy In The Acceptance Of High School New Students Year 2017/2018
In Samarinda, Jurnal Riset Pembangunan, 1 (1), 48-57. Republika.co.id, Rabu 16 Januari 2019 Rugaiyah, Sismiati, A., 2011, Profesi Kependidikan, Bogor: Ghalia Indonesia, hal. 54

Sallis, E. 2010. Total Quality Management In Education: Manajemen Mutu Pendidikan. Terjemahan Riyadi, A.A. Yogyakarta: IRCiSoD.

Sukardi, 2014, Evaluasi Program Kependidikan dan Kepelatihan, Jakarta: Bumi Aksara

Sularto, Wahyudi, Sukmawati, 2018, The Admission of New Students Based on Online System at SMAN 2 Singkawang, Journal of Education, Teaching and Learning 3 (2), 336-341.

UU No. 20 Tahun 2003 Tentang Sistem Pendidikan Nasional

UU Pendidikan Nasional No. 2/1989 tentang Wajib Belajar 9 Tahun.

Wirawan, 2011, Evaluasi Teori Model Standar Aplikasi dan Profesi, Contoh Aplikasi Evaluasi Program: Pengembangan Sumber Daya Manusia, Program Nasional Pemberdayaan Masyarakat (PNPM) Mandiri Pedesaan, Kurikulum, Perpustakaan, dan Buku Tes, Jakarta: Raja Grafindo Persada. 